\title{
Editorial note: special issue on regional prices
}

\author{
Georg Hirte
}

Accepted: 5 December 2007 / Published online: 11 January 2008

(C) Springer-Verlag 2008

For more than one century regional scienctists have been working on spatial prices. This research has generated a rich world of theoretical results and empirical evidence clearly showing that regional price differences affect all kinds of economic activities. This concerns, for example, the location decision of firms (e.g., Launhardt 1885, Weber 1909), the internal structure of cities (e.g., Alonso 1964) or the spatial pattern of economic activities including flows of goods and services (e.g., Krugman 1991). On the other hand there is a large literature in regional science focusing on the causes of explaining spatial price differences such as differences in technology, local costs and taxes, price setting behavior of firms (e.g., Hotelling 1929), differences in local amenities (e.g., Roback 1982) or transportation costs and differences in agglomeration effects (e.g., Krugman 1991).

Despite this excellent body of knowledge and the well established importance of regional prices, data on regional prices are hardly available, except for wages and prices for building land or, sometimes, housing prices. This constitutes an obstacle for empirical research in regional science and other fields of economics, such as fiscal federalism or social policy. Against this background the German speaking section (GfR) of the European Regional Science Association International (ERSA) and the Institute of Employment Research (IAB) of the German Federal Labour Office jointly organized a workshop on "Regional Prices", which took place in Dresden in July 2006. The idea was, first, to collect some stimulating papers on regional prices and, second, to bring together empirical researchers from the Statistical Offices and empirical scientists to discuss how to deal with the problem of lacking price data. Tönu Puu accepted the invitation to give the keynote speech. The papers collected in this special issue were all presented at this workshop and were peer-reviewed. They are connected to different and prominent fields of research in regional prices.

\section{G. Hirte (凶)}

Technische Universität Dresden, 01062 Dresden, Germany

e-mail: georg.hirte@tu-dresden.de 
Three of the papers contribute to the theoretical literature. Here prices are one of the main forces to structure the economy. The continuous space modelling approach, reviewed and extended by Tönu Puu is a more general approach to analyze space and, thus, spatial prices. The basic model implements a price scalar field derived by minimizing transport costs (Beckmann 1952). The model can be fully based on prices, since prices are dual to the flow of goods. A multiproduct version of the model allows to reproduce findings of von Thünen or Lösch. It also provides general results concerning a spatial pattern of central cities and the periphery. Further suggested applications are migration, business cycles and traffic flows. They all emphasize the potential of the continuous space modelling to serve as a framework for examining spatial issues, which "could also overbridge the unfortunate gap between economics and geography" (Puu, this issue).

Gunther Maier develops a new model where a Hotelling-type approach is linked with a search model and a model of the New Urban Economy. In contrast to the theoretical literature on spatial price setting or location decision, he explicitly considers the shopping and location decisions of consumers. Depending on prices and transport costs a spatial pattern of high and low densities of consumers emerge. In the center of the market areas land prices are higher but good prices are lower. The model shares some important features with the core-periphery model (Krugman 1991). The relocation of consumers together with the relocation of producers generate circular causality. The model also provides a variety of spatial price structures and exhibits a thomahawk bifurcation. With high transport costs, suppliers relocate according to the principle of maximum spatial differentiation which yields a polycentric pattern of location. In contrast, at low transport costs a monocentric pattern appears.

Jens Südekum applies an extended, analytically solvable model in the tradition of the new economic geography to analyze the consequences of differences in costs-ofliving. Besides regarding housing prices he is the first to explicitly consider consumer amenities in a general equilibrium framework. This generates some surprising results, for instance, that living costs in the agglomeration might be lower or higher. In addition, if amenities differ between regions, a full dispersion equilibrium is not feasible. Since they constitute an agglomeration force, agglomeration might be pushed into the direction of the amenity abundant region. Furthermore, amenities only capitalize in higher housing prices and lower wages if the economy is not at a corner equilibrium. Otherwise, they only capitalize in higher housing prices.

The remaining four papers are empirical studies concerning price prediction, price differences and price competition. Uwe Blien, Hermann Garnter, Heiko Stüber and Katja Wolf examine the agglomeration wage differential and regional price levels. They suggest to use the Multiple Imputation Method to overcome missing price information. This approach is evaluated and applied to predict regional price indices for regions in West Germany. Using this forecast they find evidence that the wage differential is fully explained by land prices, individual characteristics and the labor composition plus differences in regional price indices. This implies that agglomeration effects occur via firms and, consequently, that amenities capitalize in regional (land) prices but not in regional wages.

Thiess Buettner and Alexander Ebertz use prices of building land to demonstrate how to generate information on the quality of life given poor data on regional prices. 
By using an exceptional data base, they utilize differences in land prices and nominal wages to infer the marginal willingness to pay for regional attributes including the quantity and the quality of public services. Using these predictions they are the first to calculate an index of the quality of life for German regions. They provide evidence that land price differences can be explained to a substantial part by capitalized differences in amenities and disamenities-geographical conditions, leisure facilities, touristic amenities and labor market conditions. In contrast, they find only little effects of both on wages.

Joachim Möller examines the determinants of building land prices, which differ remarkably in West Germany. He develops a stylized search-theoretical model with absentee landlords. In this model the willingness to pay for building land is closely related to the labour market condition, particularly, to the workers inter-temporal value of employment, which depends on the wage offer distribution, the wage levels and the expected employment stability. In his study on West Germany he finds evidence that the labor market is actually important for building land prices. Moreover spatial dependence of first and second order is significant as well as distance to the next agglomeration and density, while tourism amenities can be neglected. This approach explains all North-South differences in regional land prices.

Dieter Pennerstorfer examines the pricing of retail gasoline stations in Austria. In this market a small number of almost perfectly homogenous products is supplied in each of the market areas by branded and unbranded gasoline stations. Pennerstorfer emphasizes two countervailing effects: (1) the competition effect: a larger number of unbranded stations strengthens competition and, thus, induces lower prices, and (2) the composition effect: since goods of branded stations are perceived as being superior to gasoline of unbranded stations, an increase in the market share of unbranded stations reduces price competition among branded stations. Moreover since gasoline is a spatially differentiated good, close competitors have a greater influence on price setting decisions. Pennerstorfer is the first to consider both effects as well as spatial dependence. He provides evidence that both effects almost fully cancel out and that spatial effects matter.

The papers collected in this issue concern different branches of the literature on regional prices. The theoretical papers offer new ideas or insights and comprise four main fields of theoretical traditions. The empirical papers provide some very interesting results concerning the causes of spatial price differences and suggest methods how to overcome data restrictions. This issue demonstrates that we need not wait for better data. There is wide scope for more research on regional prices.

\section{References}

Alonso W (1964) Location and land use. Harvard University Press, Cambridge Beckmann MJ (1952) A continuous model of transportation. Econometrica 20:643-660

Hotelling H (1929) Stability in competition. Econ J 39:41-57

Krugman P (1991) Increasing returns and economic geography. J Polit Econ 99:483-499

Launhardt W (1885) Mathematische Begründung der Volkswirtschaftslehre. W. Engelmann, Leipzig

Roback J (1982) Wages, rents, and the quality of life. J Polit Econ 90:1257-1277

Weber A (1909) Über den Standort der Industrien. JCB Mohr, Tübingen 